\title{
METHODOLOGY TO INCREASE OIL RESERVES BY IDENTIFYING OPTIMAL TIME TO ABANDON NON-ECONOMIC WELLS
}

\author{
Publio-Alejandro Sandoval ${ }^{*}$, Fabián-Ricardo Fernández ${ }^{2 *}$, Aníbal Ordóñez-Rodríguez ${ }^{1}$, \\ Claudia Rincón-Bonilla ${ }^{2}$ and Leydy Johana Jeréz ${ }^{2}$ \\ ' Ecopetrol S.A. - Instituto Colombiano del Petróleo (ICP), A.A. 4185 Bucaramanga, Santander, Colombia. \\ ${ }^{2}$ Ecopetrol S.A. - Gerencia Región Central, Bogotá, Cundinamarca, Colombia. \\ e-mail: publio.sandoval@ecopetrol.com.corfabian.fernandez@ecopetrol.com.co
}

(Received May. 31, 2011 ; Accepted Oct. 26, 2011)

\begin{abstract}
$\mathrm{E}$

timating reserves is one of the most important tasks in the oil industry. It is the process that determines the recoverable oil in a field, area or region. However, incorporating the production of a well beyond its economic limit has the effect of loss of value, because it forces economically good wells to sustain those that are not. A corporate vision of the topic, calls for greater attention to strategies to select wells for abandonment, as an important variable in the planning of production scenarios and estimating reserves. The purpose of this paper is to describe the methodology used to obtain higher value in reserves calculated for a given asset, by analyzing direct production costs and the design of an optimum well abandonment timetable.

The methodology can be applied in all the fields in which an analysis of this type has not been considered, which run the risk of having incorporated in their reserve estimate a number of wells in which the economic balance is negative, thus affecting the performance of the reservoir's better wells.

Additionally, it includes a case application of the methodology involving a field in a Colombian basin. The results show a 5 year extension in economic limit, with a significant increase in the amount of the asset's recoverable reserves.
\end{abstract}

Keywords: Economic limit, Abandonment, Benefit, Economic analysis, Feasibility studies, Reserves, Decline.

Citation: Sandoval, P. A., Fernández, F. R., Ordóñez, A., Rincón, C. \& Jeréz, L. J. ( (2011). Methodology to increase oil reserves by through identification of optimum time to abandon non-economic wells. CT\&F - Ciencia, Tecnología y Futuro, 4 (4), 37-46.

*To whom correspondence should be addressed 


\section{RESUMEN}

$\mathrm{L}$

a estimación de reservas es una de las tareas más esenciales en la industria petrolera. Este es el proceso por el cual se determina el petróleo recuperable de un campo, área o región. Sin embargo, incorporar la producción de un pozo más allá de su límite económico tiene un efecto de pérdida de valor, ya que obliga a pozos que son económicamente buenos a sostener aquellos que no lo son. Una visión corporativa del tema, exige una mayor atención a las estrategias de selección de pozos candidatos a abandono, como variable importante en la planeación de escenarios de producción y estimación de reservas. Este artículo tiene como objetivo describir la metodología utilizada para obtener un mayor valor en las reservas calculadas para un activo dado, mediante el análisis de costos directos de producción y el diseño de un calendario optimo de abandono de pozos.

La metodología tiene aplicación en todos los campos en los cuales no se haya considerado un análisis de este tipo, que presenten el riesgo de tener incorporado en su estimación de reservas alguna cantidad de pozos en los cuales su balance económico sea negativo, y se encuentre afectando así, el desempeño de los mejores pozos del yacimiento.

Adicionalmente se incluye un caso de aplicación de la metodología el cual corresponde a un campo en una cuenca colombiana. Los resultados muestran una ampliación de 5 años en su límite económico, con un importante incremento en la cantidad de reservas recuperables del activo.

Palabras claves: Límite económico, Abandono, Beneficio, Análisis económico, Estudios de factibilidad, Reservas, Declinación.

\section{RESUMO}

\footnotetext{
estimativa de reservas é uma das tarefas mais essenciais na indústria petroleira. Este é o processo pelo qual é determinado o petróleo recuperável de um campo, área ou região. Porém, incorporar a produção de um poço além de seu limite econômico tem um efeito de perda de valor, já que obriga a poços que são economicamente bons a sustentar aqueles que não o são. Uma visão corporativa do tema exige uma maior atenção às estratégias de seleção de poços candidatos ao abandono, como variável importante no planejamento de cenários de produção e de estimativa de reservas. Este artigo tem como objetivo descrever a metodologia utilizada para obter um maior valor nas reservas calculadas para um ativo dado, mediante a análise de custos diretos de produção e do desenho de um calendário ótimo de abandono de poços.
}

A metodologia tem aplicação em todos os campos nos quais não foi realizada uma análise deste tipo, que apresentem o risco de ter incorporado em sua estimativa de reservas alguma quantidade de poços nos quais seu balanço econômico seja negativo e esteja afetando, assim, o desempenho dos melhores poços da jazida.

Adicionalmente, foi incluído um caso de aplicação da metodologia o qual corresponde a um campo em uma bacia colombiana. Os resultados mostram uma ampliação de 5 anos em seu limite econômico, com um importante aumento na quantidade de reservas recuperáveis do ativo.

Palavras-chaves: Limite econômico, Abandono, Benefício, Análise econômica, Estudos de factibilidade, Reservas, Declinação. 


\section{INTRODUCTION}

In the hydrocarbon industry, reserves are defined as the volume of oil that can be produced both financially and technically; therefore, they are only the exploitable and recoverable part of an accumulation at a given time and price. Reserves have to be estimated in order to evaluate the value of the oil and gas assets, and to meet the demands of information imposed on oil companies and by different government and regulatory agencies (Palke \& Rietz, 2001).

Proven developed reserves are defined as the volumes of hydrocarbon that are going to be produced by existing wells with the current infrastructure and/or with moderate capital investments (Etherington \& Hunt, 2004). On the other hand, proven undeveloped reserves are those that are going to be produced by future wells.

Normally, reserve estimate methods are classified into three families: analogies, volumetric and performance analysis. Assessment methods based on performance, in turn, are divided into material balance, reservoir simulation, and decline analysis (Bradley, 1987).

Estimating ultimate recovery by decline curve analysis is one of the most commonly used methods in the assessment of reserves and the prediction of the future behavior of a well or an asset (Zhigang, 1991). The basic assumption in this procedure is that all phenomena that would have affected the tendency of a curve in the past will continue this trend in the future in a uniform manner.

The life of a well goes through many stages. The first one is the discovery of a new oil or gas reservoir, after months or years of exploration. The achievement of the first production is another important goal. The success of enhanced recovery operations can make this stage of the production very rewarding from the financial and technical standpoints. The stage that nobody seems to enjoy is the completion of the production and abandonment of wells and production facilities (Barclay et al., 2002).

Antia, 1994, summarizes the economic strategies designed to maximize the benefits associated with abandonment decisions, focusing mainly on:

- Extending the life of the field.
- Compensating a third party for the economic risks.

- Re-using facilities and infrastructure.

In an oil field, wells are usually abandoned for two main reasons: the first is due to the problems that come up during the stages of drilling or completion, where wells become irreparable, thus requiring their abandonment.

The second most common cause is when production reaches its economic limit, i.e. when keeping the well in operation requires more money and/or energy than it produces. (Hook, 2009)

A well reaches its economic limit when the oil produced is not enough to cover operating and maintenance costs, so the well becomes economically unproductive. Determining this economic limit from one well to another is an exercise that has not been implemented up to now, mainly due to the large amount of information coming from the financial area of the asset and the lack of a strategy for the reservoir engineer to incorporate this information in the reserve forecast. In contrast, the strategy that is followed is the definition of a single fixed rate or "technical limit" for all the wells on the field, which can lead to the incorporation of non-economic portions of the curves for each well in the projection of the asset's total fluids. This poor practice is a disservice given that the total benefits are diminished by said noneconomic portions.

This methodology has been designed to provide a clear procedure to plan abandonment Schedule, and thereby generate synergy between reservoir and financial areas, for the efficient management of assets. Similarly, it is meant to emphasize the economic contributions that can be achieved as an increase in the Net Present Value (NPV), and the improvement of the projection of the asset's variable costs in order to make the implementation of new technologies more feasible to further the assets' recovery factor goals.

\section{THEORETICAL FRAMEWORK}

When there is enough production data, and production is declining, the historic production curves 
of each individual well can be extrapolated in order to define future behavior. The truth of the matter is that many aspects can influence production rates and, consequently, the curves of decline, including prorating, changes in production methods, stimulation and market conditions, among others.

In the industry, there are currently three accepted models of decline as far as conventional deposits: Exponential, hyperbolic and harmonic, although the most commonly used is the exponential model because the results thereof are more conservative compared to those obtained using the other two techniques.

When the logarithm of the oil rate vs. time is a straight line, it is said that the method is exponential; but when the chart shows a degree of curvature, it involves harmonious or hyperbolic decline as illustrated in Figure 1 (Satter \& Thakur, 1998).

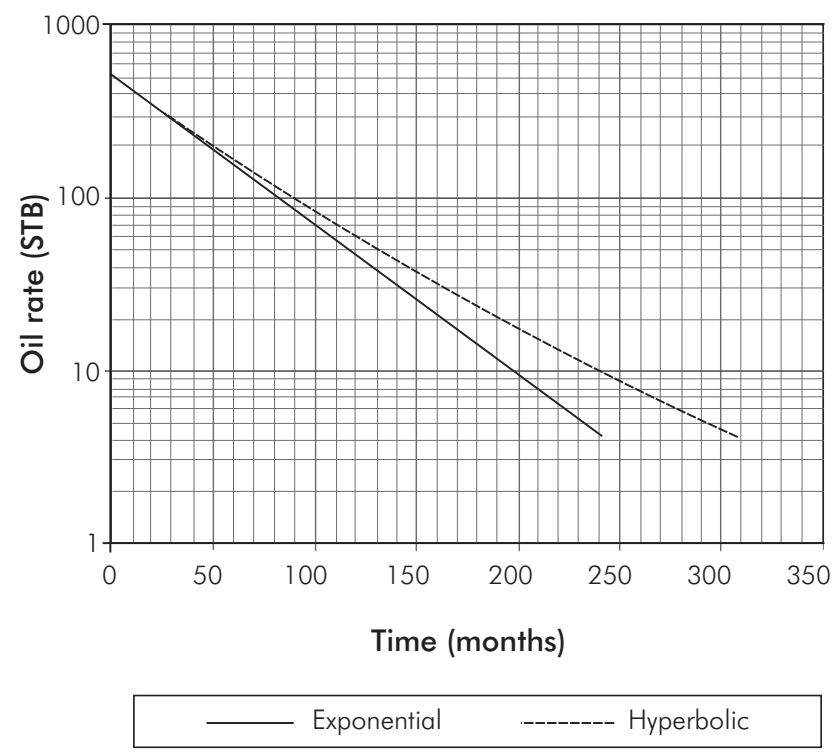

Figure 1. Projection of reserves by decline curves.

A commonly used mathematical expression for the decline rate submitted by Satter \& Thakur (1994):

$D=\frac{d q / d t}{q}=K q^{n}$
Arps (1956), presents mathematical expressions for the three types of decline (exponential, harmonious and hyperbolic).

\section{Projected Water Production}

Another key element in estimating reserve is the estimation of water associated with oil production. This is a fundamental element in the process because the inadequate estimation of these volumes will entail deviations in the estimated costs, eventually affecting the projection of the asset's productive life.

An easy way to calculate the water produced is the subtraction between the total fluids produced and the oil produced. However this estimate involves risks because it assumes that the total fluids produced in the reservoir remain constant over time. The trend of total fluids has to be estimated to determine whether they are declining.

A simple chart of waterflood vs. cumulative oil (Satter \& Thakur, 1998) facilitates the projection over time of the total fluid produced and expected water volumes (See Figure 2).

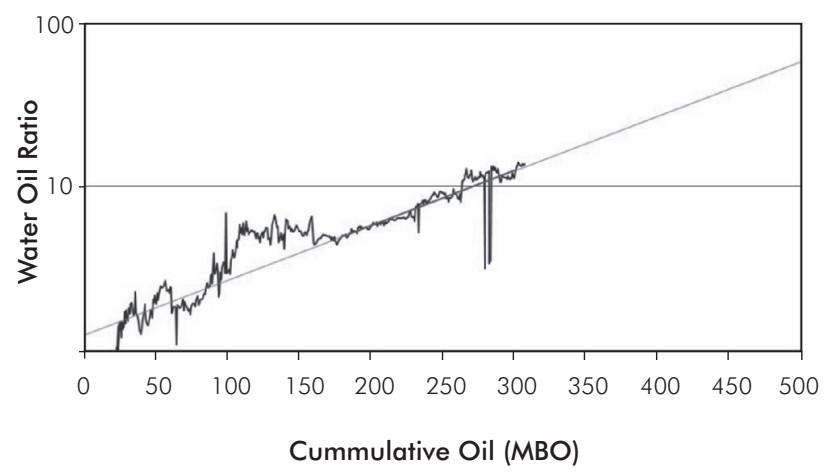

Figure 2. Projecting the behavior of waterflood.

\section{Economic Limit}

Economic limit is defined as the last point on the decline curve in which the oil produced pays the direct development costs. When determining the economic limit, it is often useful to analyze what costs should be charged to each production well and how much of these costs will actually be saved as a result of abandoning the well. 


\section{METHODOLOGY}

The methodology is based largely on a balance sheet of the revenues produced by the sale of oil and gas, month by month, at each of the wells and the expenditures due to maintenance costs, energy, separation, treatment and reinjection of the water produced. This can be summarized in the 4 fundamental steps listed below:

\section{Adjusting Historic Trends}

At this stage, as illustrated in Figure 3, historical information on production is collected, charts are created of each of these rates vs. time and tendency lines are defined for each of the fluids produced (Satte \& Thakur, 1998). Primarily, a historical analysis of the oil produced is carried out, a trend line is identified and this behavior is extrapolated over time in order to have an idea of the future volumes to be produced in the well being analyzed. Normally, in projecting oil, the above processes are rigorous and conservative because these curves usually are audited by companies specializing therein. This methodology suggests that the same rigor should be used in the adjustment and projection of other fluids produced because they are a source of opex and an erroneous projection can affect the economy of the well and the asset to a certain degree.

\section{Defining Economic Parameters}

During this stage, a search is performed and all the costs directly associated with production are classified and analyzed. Once these items have been defined, they are converted to unit values as illustrated below:

- Cost associated with the energy consumed (US\$/ day/well).

- Cost associated with well maintenance (US\$/day/ well).

- Cost associated with oil production (US\$/barrel oil).

- Cost associated with gas production (US\$/ $\mathrm{ft}^{3} \mathrm{stan}-$ dard gas).

- Cost associated with water production (US\$/barrel water).

- Royalties (US\$/barrel oil).
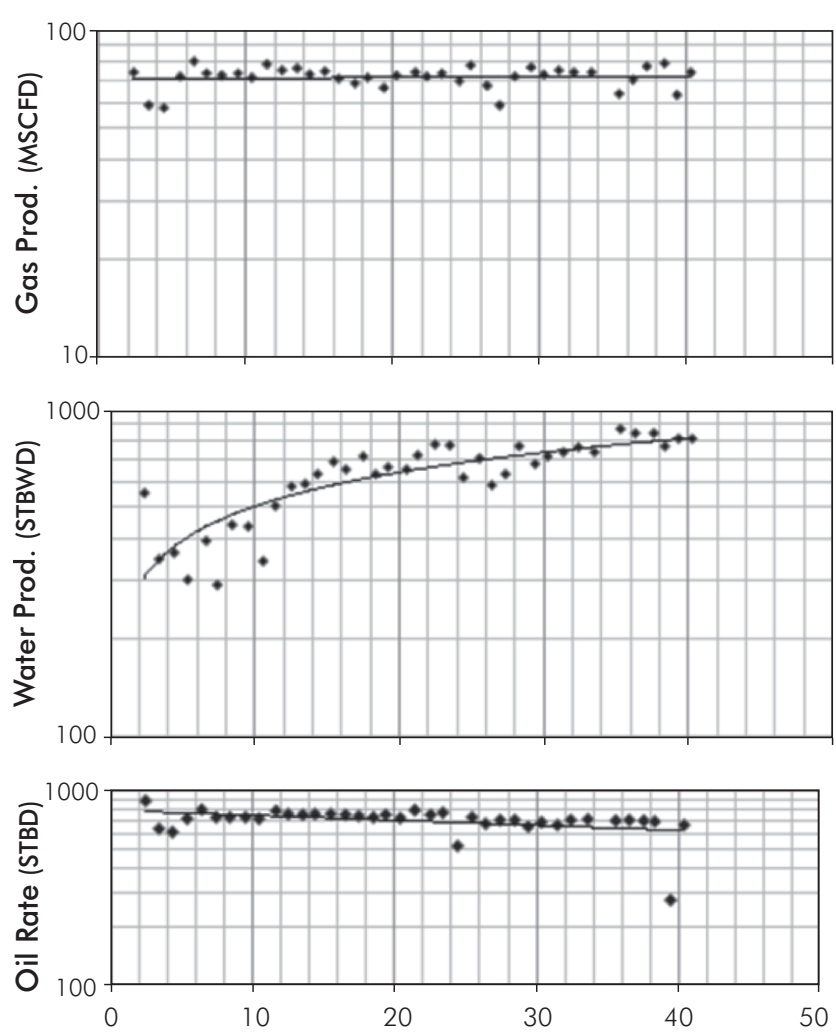

Figure 3. Definition of trends in the historical fluids produced.

Mainly, the idea is to link a unit cost to each and every one of the expenses directly associated with the operation. In order to do so, it is important to have the support of the group that handles the financial aspect of the asset, since it is the most reliable, accurate source to find this information.

\section{Economic Balance}

Once the fluid projections and unit costs are available, they are crossed with each other in an economic balance, well by well, and the rate at which each of the wells ceases to be economic is determined.

The equation illustrates how this balance is carried out.

$B=q_{o} O_{p}+q_{g} V G_{p}-q_{o} R-q_{o} O_{c}-q_{w} W_{c}-q_{g} G_{c}-E_{c}-M_{c}$

Although the equation may seem long, it is no more than a sum of revenues and expenditures due to well production. This balance is performed every month until you find the point at which revenues no longer outweigh 
the expenditures. Said point is called the economic limit and that is where the well should be abandoned.

\section{Calculating Reserves}

The calculation of reserves consists of adding the oil produced by the well month by month, until the total oil expected to be produced by the well is found during the interval between the start time of the projection and the economic limit of the well. The total reserves developed correspond to the sum of the reserves producible by all existing wells in the asset.

\section{RESULTS}

Table 1 is an illustration of the suggested methodology compared to the methodology that has been applied traditionally. The colored cells have an associated oil rate value greater than zero. However, the sign indicates whether production is in fact generating profits for the asset or not.

Setting a single limit oil rate causes the oblivious inclusion of non-economic segments with the damages mentioned earlier. The upper grid of the chart shows that although wells 2 and 3 are in negative balance during the period between $t(n)$ to $t(n+2)$, the total balance of the field is still positive, because all the other wells still have a production that is good enough to subsidize these losses. However, at point $t(n+3)$ in time, well 4 goes into a negative balance, making said subsidy no longer feasible and, consequently, the total balance of the field also begins to generate losses. Certifiable reserves for this asset will only be those between the initial time and point $t(n+2)$ in time, regardless of whether the production of the wells has been projected much later in time.

Table 1. Methodology of cost analysis in the optimal abandonment of wells.

\begin{tabular}{|l|c|c|c|c|c|c|c|}
\hline & $t(n)$ & $t(n+1)$ & $t(n+2)$ & $t(n+3)$ & $t(n+4)$ & $t(n+5)$ & $t(n+6)$ \\
\hline Well 01 & + & + & + & + & + & + & + \\
\hline Well 02 & + & - & - & - & - & - & - \\
\hline Well 03 & + & + & - & - & - & - & - \\
\hline Well 04 & + & + & + & - & - & - & - \\
\hline Well 05 & + & + & + & + & + & + & + \\
\hline Well 06 & + & + & + & + & + & + & + \\
\hline TOTAL & + & + & + & - & - & - & - \\
\hline & $+(n)$ & $t(n+1)$ & $t(n+2)$ & $t(n+3)$ & $t(n+4)$ & $t(n+5)$ & $t(n+6)$ \\
\hline Well 01 & + & + & + & + & + & + & + \\
\hline Well 02 & + & & & & & & + \\
\hline Well 03 & + & + & & & & & + \\
\hline Well 04 & + & + & + & & & & + \\
\hline Well 05 & + & + & + & + & + & + & + \\
\hline Well 06 & + & + & + & + & + & + & + \\
\hline TOTAL & ++ & ++ & ++ & + & + & + & + \\
\hline
\end{tabular}


In the grid at the bottom of Table 1, the cells that are not shaded and have no sign representing the abandonment of wells. This shows the impact of abandoning wells right when they are going to begin to have a negative balance. A greater benefit can be observed in the total balance of the field, during the period between $t(n)$ to $t(n+2)$, which is represented in the chart as a doublepositive $(++)$, which is logical bearing in mind that during this period, the production of non-economic wells is no longer being subsidized. In addition, and for the same reasons, the period between $t(n+3)$ and $t(n+6)$ is now viable, because of the gain in the life of the asset and in reserves. Finally, there will be a point at which the field also becomes negative, but this is because the earnings from the wells that are still in operation at this moment, can no longer pay the fixed costs of the field.

Figure 4 shows the projection of oil and water obtained for the case application using the two methodologies. It shows that the sacrifice in the oil rate is not very strong;

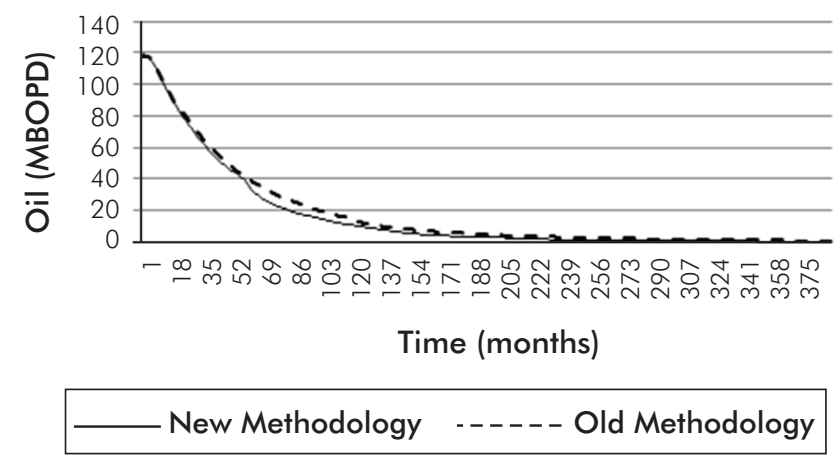

(a) however, the projection of water production with the new methodology is considerably lower.

Figure 5 shows how the growth of "lifting cost" is projected with both methodologies for the case study. It shows that the growth of these parameters is more controlled by using the methodology for optimal abandonment.

Table 2 shows a comparison between the reserves calculated and the net present value expected in the total financial analysis of the field using either methodology. It shows that scheduling the abandonment of wells at the right time generated, for the case study in particular, the incorporation of 5 million in reserves with a benefit of US $\$ 139$ million in addition to the amount calculated using the old methodology.

Finally, Table 3 shows that, with the traditional methodology, the economic limit is reached in 111 months, compared to the new methodology, with a time of 192 months as the economic limit of the asset.

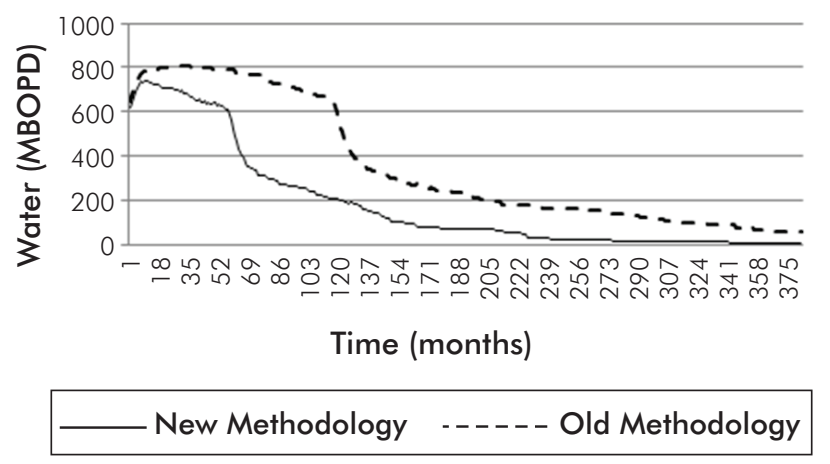

(b)

Figure 4. Water and oil production.

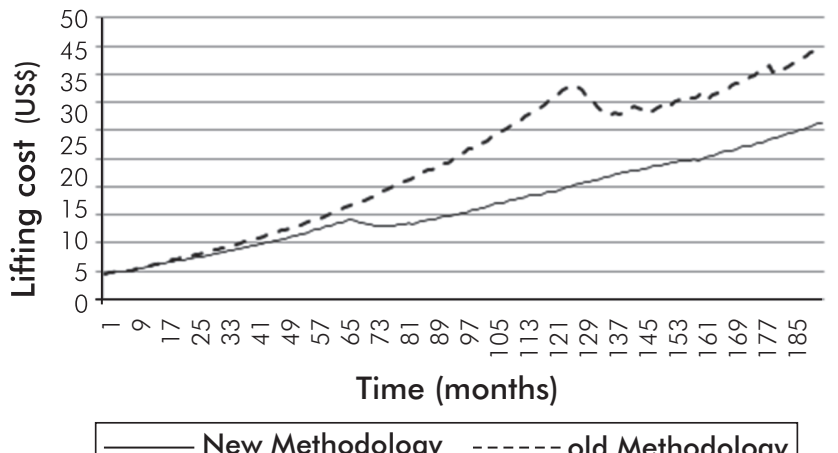

Figure 5. Liffing Cost. 
Table 2. Benefits of the methodology.

\begin{tabular}{|c|c|c|}
\hline Time (months) & 1 & 2 \\
\hline Oil & 104458 & 106834 \\
\hline Water & 439924 & 476154 \\
\hline Wells & 140 & 141 \\
\hline Gross_fluid_opex & 402842 & 431412 \\
\hline All wells opex & 26573 & 26573 \\
\hline Power opex & 5870 & 5912 \\
\hline Fixed cost & 39740 & 39740 \\
\hline Income & 3290415 & 3365284 \\
\hline Renueves bit & 2815578 & 2861647 \\
\hline$\underline{\text { Lifyng cost (Calculated) }}$ & $\$ 5$ & $\$ 5$ \\
\hline VPN & $\$ 3270622771$ & \\
\hline Reserves & 209662318 & \\
\hline
\end{tabular}

New Methodology

(a)

\begin{tabular}{|lrr|}
\hline \multicolumn{1}{|c}{ Time (months) } & 1 & 2 \\
\hline Oil & 104472 & 106834 \\
\hline Water & 441353 & 476154 \\
\hline Wells & 139 & 141 \\
\hline Gross_fluid_opex & 403911 & 431412 \\
\hline All wells opex & 26573 & 26573 \\
\hline Power opex & 5912 & 5912 \\
\hline Fixed cost & 39740 & 39740 \\
\hline Income & 3365284 & 3365284 \\
\hline Renueves bit & 2861647 & 2861647 \\
\hline Lifyng cost (Calculated) & & $\$ 5$ \\
\hline VPN & $\$ 3131795704$ & \\
\hline Reserves & 204542205 & \\
\hline
\end{tabular}

Old Methodology

(b)

Table 3. Economic limit of the asset.

\begin{tabular}{|lrrr|}
\hline \multicolumn{1}{|c}{ Time (months) } & 191 & 192 & 193 \\
Oil & 3158 & 3135 & 3112 \\
\hline Water & 70684 & 70707 & 70730 \\
\hline Wells & 17 & 17 & 17 \\
\hline Gross_fluid_opex & 54643 & 54643 & 54643 \\
\hline All wells opex & 3204 & 3204 & 3204 \\
\hline Power opex & 713 & 713 & 713 \\
\hline Fixed cost & 39740 & 39740 & 39740 \\
\hline Income & 99489 & 99489 & 98022 \\
\hline Renueves bit & 1189 & 452 & -278 \\
\hline Lifyng cost (Calculated) & $\$ 31$ & $\$ 31$ & $\$ 32$ \\
\hline
\end{tabular}

New Methodology

(a)

\begin{tabular}{|lrrr|}
\hline \multicolumn{1}{|c}{ Time (months) } & 110 & 111 & 112 \\
\hline Oil & 19385 & 19058 & 18736 \\
\hline Water & 688,661 & 687661 & 685873 \\
\hline Wells & 165 & 165 & 163 \\
\hline Gross_fluid_opex & 523954 & 523954 & 521411 \\
\hline All wells opex & 31096 & 31096 & 30719 \\
\hline Power opex & 6918 & 6918 & 6834 \\
\hline Fixed cost & 39740 & 39740 & 39740 \\
\hline Income & 610621 & 610621 & 590185 \\
\hline Renueves bit & 8913 & 8913 & -8519 \\
\hline Lifyng cost (Calculated) & $\$ 31$ & $\$ 31$ & $\$ 32$ \\
\hline
\end{tabular}

\section{Old Methodology}

(b)

\section{DISCUSSION}

Abandoning wells, taking into account economic balance, has a significant impact on the amount of water produced. This is because in the non-economic portions of the production curve of each well, there is a very high waterflood and very little oil. This explains

the major difference observed in the production of water illustrated in Figure 4.

Not producing unnecessary volumes of water, as mentioned earlier, generates a favorable impact on the environment, because there is a benefit represented in the energy saved by not having to pump said fluid. Further 
savings are generated when it comes to the amount of chemicals that would be required if this amount of water had to be treated. Finally, more savings are generated from the energy that would be used if these volumes had to be re-injected or dumped.

At present, one of the biggest concerns of reservoir managers is the rate at which the value of lifting cost increases. Figure 5 shows how this parameter is projected in a more controlled manner. If you look carefully, you can see how in month 101, with the previous methodology, the lifting cost rose to US \$30 per barrel, while with the new methodology, it barely reaches a value of $\$ 15$ per barrel. It is very likely that the proper abandonment of wells is not the only cause for said growth, but the results show a significant contribution in controlling the problem.

\section{CONCLUSIONS}

- The implementation of this methodology will allow the more reliable definition of well abandonment schedules and the more efficient management of resources.

- The need to calculate the rates associated with each of the fluids, wells, and energy, generates synergy between teams for the optimal management of the assets.

- The controlled growth of the "lifting cost" helps make the evaluation of new projects viable and leverages the implementation of new technologies in our fields.

- As illustrated, the implementation of the methodology generates an increase in reserves by increasing the life of the best wells.

- The methodology somehow plays a role in the environment because it helps reservoir engineers to plan abandonment at the right time, thus avoiding the unnecessary production of volumes of water that would otherwise require both treatment and energy to be reinjected.

\section{ACKNOWLEDGMENTS}

The authors would like to express our gratitude to the Ecopetrol S.A. - Instituto Colombiano del Petróleo (ICP) for its financial, scientific and staff support in this work. We would also like to thank the following individuals for their support and comments: Adriano Lobo, Carlos Chaparro and Jorge Mantilla.

\section{REFERENCES}

Antia D. (1994). Maximizing Profits Associated With Abandonment Decisions And Options. SPE 7477-MS.

Arps J. J. (1956). Estimation of primary oil reserves. Petroleum Transactions, AIME. 207: 182-191.

Barclay I, Pellenbarg J, Tettero F, Pfeiffer J, Slater H, Staal T, Stiles D, Tilling G, \& Whitney C. (2002). El Principio del Fin: Revisión de las practicas de abandono y desmantelamiento. Oilfield Review: 28-41

Bradley H. (1987). Petroleum Engineering Handbook. Texas, U.S.A: SPE. Richardson

Etherington, J. \& Hunt, E. (2004). Can You Have Probable Without Proved Reserves?. Society of Petroleum Engineers, SPE 90241-MS.

Hook M. (2009). Depletion and Decline Curve Analysis in Crude Oil Production. Uppsala Sweden: Department for Physics and Astronomy, Uppsala University.

Palke M. \& Rietz D. (2001). The Adaptation of Reservoir Simulation Models for Use in Reserves Certification Under Regulatory Guidelines or Reserves Definitions. Society of Petroleum Engineers SPE 71430- MS.

Satter, A. \& Thakur G. (1994). Integrated Reservoir Management. Tulsa Oklahoma: Pen Well Publishing Company.

Satter, A. \& Thakur G. (1998). Integrated Waterflood Asset Management. Tulsa Oklahoma: Pen Well Publishing Company.

Zhigang, C. (1991). A Detecting Technique for Production Rate Decline-Curve Analysis with Residual Plots. Society of Petroleum Engineers SPE 22313 - MS. 


\section{NOTATION}

$B \quad$ Balance (US\$/day)

$E_{c} \quad$ Cost of energy (US\$/day-well)

$G_{C} \quad$ Gas production cost (US\$/scf)

$G_{P} \quad$ Gas sale price (US\$/scf)

K Constant

$M_{C} \quad$ Maintenance cost (US\$/day-well)

$n \quad$ Exponent

$O_{c} \quad$ Oil production cost (US\$/bbl)

$O_{p} \quad$ Price per barrel of oil (US\$/bbl)

$q \quad$ Production rate, barrels/day

$q_{g} \quad$ Gas rate (scf/day)

$q_{o} \quad$ Oil rate (bbl/day)

$q_{w} \quad$ Water rate (bbl/day)

$R \quad$ Royalties

$t \quad$ Time, days

$V \quad$ Fraction of gas destined for sale.

$W_{c} \quad$ Water production cost (US $\left.\$ / \mathrm{bbl}\right)$

D Declinate Rate 